ERRATUM OPEN

\title{
Erratum: Hybrid graphene tunneling photoconductor with interface engineering towards fast photoresponse and high responsivity
}

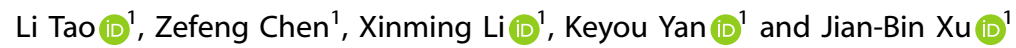

npj 2D Materials and Applications (2017)1:32; doi:10.1038/s41699-017-0028-0

Erratum to: npj 2D Materials and Applications (2017); doi:10.1038/ s41699-017-0016-4; Published 03 July 2017

In the original PDF version of this paper, ' $\tau$ ' was omitted from ' $\tau_{\text {tunnel }}$ in equation 1.

This correction has been made to the PDF version of this article.

cc (i) Open Access This article is licensed under a Creative Commons Attribution 4.0 International License, which permits use, sharing, adaptation, distribution and reproduction in any medium or format, as long as you give appropriate credit to the original author(s) and the source, provide a link to the Creative Commons license, and indicate if changes were made. The images or other third party material in this article are included in the article's Creative Commons license, unless indicated otherwise in a credit line to the material. If material is not included in the article's Creative Commons license and your intended use is not permitted by statutory regulation or exceeds the permitted use, you will need to obtain permission directly from the copyright holder. To view a copy of this license, visit http://creativecommons. org/licenses/by/4.0/.

(c) The Author(s) 2017 